\title{
Diagnostic \& immunological study on Aspergillus fumigatus of camels in Thi-Qar province
}

\author{
A.J. Na'ma \\ Coll. of Vet Med./Univ. of \\ Al-Qadissiya
}

A. I. Al-Ameed

Coll. of Vet Med./Univ. of

Baghdad

\author{
M. H. Hussain \\ Coll. of Vet Med./Univ. of \\ Al-Qadissiya
}

\section{Abstract}

Fungi have an important role as an etiological factor in respiratory tract disorders in farm animals. In camels, this study was conducted to discover the immune status against Aspergillus fumigatus ; the most common fungi in the world. 90 camels were inspected and the blood was sampled from herds in Thi Qar governorate. Camels ranked in different ages, 1-10 years, and both male and female were included. The study dialed with camels suffering respiratory disorder. Serum was examined by passive hemagglutination test using the antigen of Aspergillus fumigatus isolated and prepared by (1). 16 camels were positive which present $17.8 \%$, this result informs an important role of Aspergillus fumigatus as a cause of respiratory tract disorder in Iraqi camels.

\section{Introduction}

The genus Aspergillus is extraordinary as exemplified by the diversity of its disease manifestations, almost all termed "aspergillosis". All forms of aspergillosis are sapronoses, that is transmissible form an abiotic environment, and not communicable from person to person, or zoonosis (2). Genus Aspergillus is a wide spread fungi around the world. Among its types; A. fumigatus is the most pathogenic type causing diseases in human \& animals. A. fumigatus is an opportunistic fungus affecting respiratory system (3). Elevated pathogenic manifestations of A. fumigatus belong to several factors; it's ability to growth faster than other types in wide range of temperature (20-50) $\mathrm{C}^{\mathrm{o}}$, A. fumigatus is highly sporelating fungus for which it has found in about (1-100) spore $/ \mathrm{m}^{3}$ in the atmosphere (4). Besides, spore ability to combine using fibrinogen \& laminine which facilitate the spore adhesion to the epithelium of respiratory tract (5). Other factor is that A. fumigatus secrets the complement inhibitor (6), seven polypeptide allergens responsible for cases of asthma \& inflammation of the mucous membranes. Other secretions have reported are $\beta-1-3$ glucan which is an immunostimmulant (7), protease \& elastease. It's thought that protease is responsible of the pathogenecity of the fungus in the lung tissue when an infection had happened (3).A. fumigatus is a zoonotic fungus (5), In animals it causes bronchitis when the spores have been inspired or ingested with contaminated diet, the case may develop to abortion in pregnant females (8). Consequently, regarding to the economic losses in animal husbendary caused by this type of pathogen \& its risk on human health. This study merged as the first in Iraq \& camels were the target animal because they present alarge part of the animal population in our country.

\section{Materials \& methods}

1- Solutions:

- Tannic acid solution 1:20000

2- The fungus Aspergillus fumigatus: diagnosed \& isolated by (1) from human suffering respiratory disorders. Antigen (Aspergillin) was extracted according to (9). Mycelium antigen was used in this study.

3- Blood samples: 90 samples of $5 \mathrm{ml}$ whole blood were collected from the jugular vein collected from camels at different sexes $\&$ ages. The camels show signs of bronchitis, mucopurulent discharge, inappetite, fever, pulmonary consolidation, on auscultation; there were rales; \& cough is a frequent symptom. Using the centrifuge; $3000 \mathrm{rpm}$ for 10 minutes to separate the serum. The complement was inhibited by putting the serum in $56 \mathrm{C}^{\circ}$ water bath for 30 
minutes $\&$ left to $\operatorname{cool} \&$ then frozen up to use.

4- Sheep blood: suspending the antigen on the red blood cells as an essential part of the passive hemagglutination test.

5- Passive hemagglutination test used to measure the titer of antibody in the serum sampled from the suspected camels. In this test; we need sheep blood to sensitize the antigen on the red blood cells (RBCs). According to Boyden (1951) RBCs were separated $\&$ washed. The $2^{\text {nd }}$ step was to use tannic acid to prepare Tanned RBCs
(TRBCs). The best titration of the aspergillin was found 1:8 which used to sensitize the antigen on the TRBCs to become sensitized RBCs (SRBCs). $0.02 \mathrm{ml}$ of $1 \%$ natural serum of the suspected camels were poured in each small pits of microtiter plates. These pits were diluted according to two fold serial dilution way, next step was to add $0.02 \mathrm{ml}$ of SRBCs to each pits \& then the plate was incubated in $37 \mathrm{C}^{\circ}$. Primary results was read after $2 \mathrm{hr}$ while the final results to be read after $24 \mathrm{hr}$.
Passive hemagglutination test has resulted positive immune response in different levels. The largest titer presented in 1:32 in 7 camels, $1: 16$ in 7 camels \& one camel positive at titer of 1:8 \& 1:4as in table (1). These results prove that these camels have infected with respiratory aspergillosis in 17.8. The rest samples didn't show any response which means they are not infected. 12 females \& 4 males were positive to the serological test, passive hemagglutination test, as illustrated in table (2). The calf camels in the first year old has the highest

\section{Results}

percentige $(37.5 \%)$. Four calves aging 2 years were infected, in the same time, camels aging 3,4,7 \& 8 have reported one case apart. Finaly, 2 cases were diagnosed in camels eld 5 years. Statistically; it was significant, according to (10), that there is an effect of age on the infection of aspergillosis as demonstrated above $\left(\mathrm{Chi}^{2}=26.7\right)$, but there was no effect of sex on this infection $\left(\mathrm{Chi}^{2}=0.06\right)$ because there were 12 positive females to 54 negative $(18.2 \%)$ against 4 positive males to 20 negative (16.7).

Table (1) titeration of antibodies against A. fumigatus in camels

\begin{tabular}{|l|l|l|}
\hline Titer & No. of positive camels & Percentage \\
\hline $1: 4$ & 1 & 1.1 \\
\hline $1: 8$ & 1 & 1.1 \\
\hline $1: 16$ & 7 & 7.8 \\
\hline $1: 32$ & 7 & 7.8 \\
\hline
\end{tabular}

Table (2) the effect of age \& sex on infection of aspergillosis

\begin{tabular}{|c|c|c|c|c|c|c|c|c|c|c|c|c|c|c|c|c|}
\hline Age & \multicolumn{2}{|c|}{1 year } & \multicolumn{2}{|c|}{2 years } & \multicolumn{2}{|c|}{3 years } & \multicolumn{2}{|c|}{4 years } & \multicolumn{2}{|c|}{5 years } & \multicolumn{2}{|c|}{6 years } & \multicolumn{2}{|c|}{7 years } & \multicolumn{2}{|c|}{8 years } \\
\hline \multirow{2}{*}{ Positive camels } & $\mathrm{F}^{*}$ & $\mathrm{M}^{*}$ & $\mathrm{~F}$ & $\mathrm{M}$ & $\mathrm{F}$ & $\mathrm{M}$ & $\mathrm{F}$ & $\mathrm{M}$ & $\mathrm{F}$ & $\mathrm{M}$ & $\mathrm{F}$ & $\mathrm{M}$ & $\mathrm{F}$ & $\mathrm{M}$ & $\mathrm{F}$ & $\mathrm{M}$ \\
\hline & 4 & 2 & 3 & 1 & 1 & 0 & 1 & 0 & 2 & 0 & 0 & 0 & 0 & 1 & 1 & 0 \\
\hline Tested camels & \multicolumn{2}{|l|}{20} & \multicolumn{2}{|c|}{10} & \multicolumn{2}{|c|}{10} & \multicolumn{2}{|c|}{10} & \multicolumn{2}{|c|}{10} & \multicolumn{2}{|c|}{10} & \multicolumn{2}{|c|}{10} & \multicolumn{2}{|c|}{10} \\
\hline Percentage & \multicolumn{2}{|l|}{0.3} & \multicolumn{2}{|c|}{0.4} & \multicolumn{2}{|c|}{0.1} & \multicolumn{2}{|c|}{0.1} & \multicolumn{2}{|c|}{0.2} & \multicolumn{2}{|c|}{0.0} & \multicolumn{2}{|c|}{0.1} & \multicolumn{2}{|c|}{0.1} \\
\hline
\end{tabular}

*F: female

$* \mathrm{M}$ : male

\section{Discussion}

A. fumigatus is the only fungal agent that far associated with systemic diseases in camels. This study has an agreement with several studies: the fungus was isolated from a five-year-old camel with chronic rhinitis, characterized by bilateral mucopurulent 
nasal discharges and mild inspiratory dyspnea. In other reference matching with this study; A. fumigatus was incriminated in the aetiology of an outbreak of bronchopneumonia and gastroenteritis that affected a large number of racing camels in the Emirates (11). The antigene used in this study has been used previously by (1) in immunizing the rabbits, the highest titer of antibody in their serum were measured 1282048 \& so it was used in this study to measure the antibody in suspected camels with infection of A.fumigatus. Consequently; it has lower titer in camel than in rabbits which reveal that aspergillosis is a chronic respiratory infection in camels. These results make this antigen as an indicator in diagnosis of this infection. Yaseen (12) has done a similar study on persons suffering respiratory disorders \& found titers 8-256 using the same test $\&$ antigen which reveal the ability of this fungus to induce the infection in human as well as in camels.

\section{References}

1- العميد, اسيل ابر اهيم (2008). عزل عفن الرشاشيات

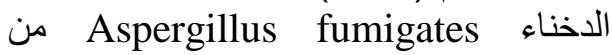

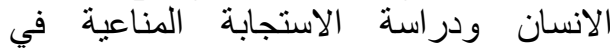

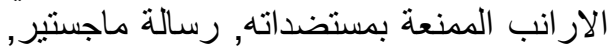
جامعة بغداد/ كلية الطب البيطري.

2-Alesandro C. P. (2010). Aspergillosis: from diagnosis to prevention. Part I, Introduction. Springer Science \& Business Media.

3-Kwon-Chung, K.J.\& Bennett, J.E.(1992). Medical Mycology. Lea \& Febiger, Philadelphia, Pa.

4-Lacey, J.(1996). Spore dispersal- its role in ecology \& disease : The British contribution of fungal aerobiology , Mycological Research 100:641660.

5-Denning, D.W. (1998). Invasive Aspergillosis. Clin. Infeet . Dis. 26:781-803.

6-Patterson, T.F. (2004). ASpergillus species. In: Principles \& Practice of Infectious diseases. Edited by Mandell , G.L.; Bennett, J.E.; Dolin, R.Vol. 26 ${ }^{\text {th }}, 2958-2973$. Philadelphia, Churchill. Livingstone.

7-Rylander, R.(1999). Indoor air- related effects \& air borne (1-3) B-D glucan. Environmental Health Perspectives 107: 501-503.

8-Richard, J.L.(1997). ASpergillosis .In : Diseases of Poultry. Edited by Clanek, B.W.; $10^{\text {th }}$ ed. Mosby Wolfe , London, UK.351-360.

9-Kurhade, A.M.; Deshmukh, J. M.; Fule, R. P.; Chade, C. \& Akulwar, S. (2002). Mycological \& serological study of pulmonary aspergillosis in central india. Indian Journal of Medical microbiology, 20(3): 141144.

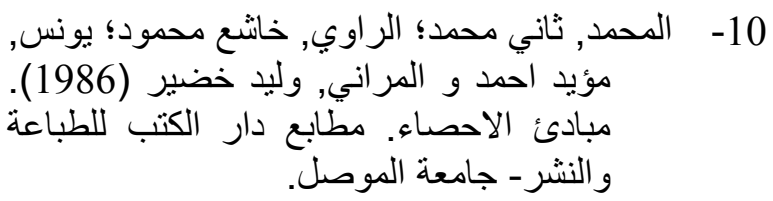

11- Abbas B. \& Omer O. H. (2004). Review of infectious diseases of the camel. Veterinary Bulletin 75(8), IN- 16N. King Saud University, KSA.

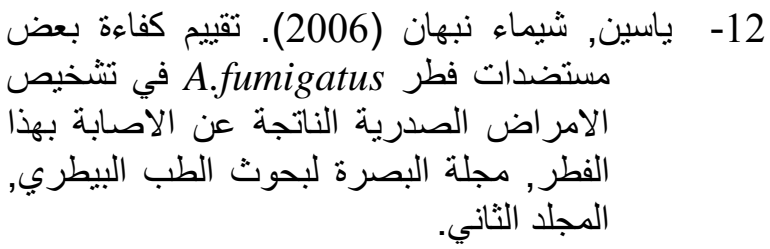




\section{دراسة تشخيصية ومناعية على عفن الرشاشيات الاخناء في الإبل العراقية

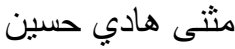 \\ أسيل إبر اهيم مظفر الرئر كلية الطب البيطري جامعة القادسية اليطري \\ كلية الطب البيطري الين البطري جامعة بغداد المباد

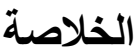 \\ احمد جاسم نعمة الطمة كلية الطب البيطري جامعة القادسية}

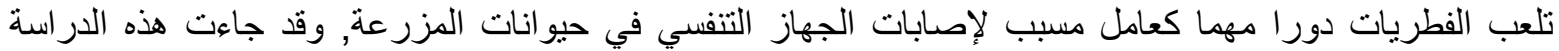

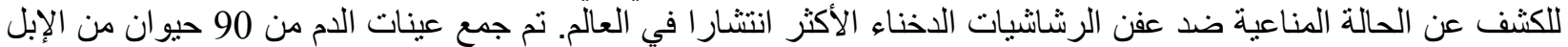

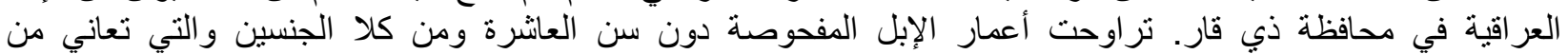

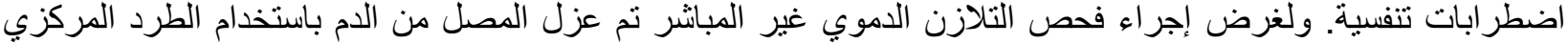

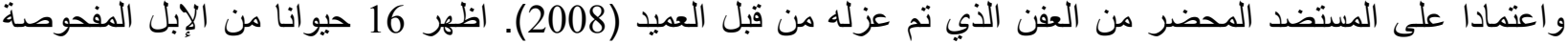
نتيجة موجبة والتي تمثل نسبة 17.8 \% و هذا ما يظهر الدور المهم لهذا العفن في الإصابات التنفسية في الإبل. 